\title{
The South-American rattlesnake Crotalus durissus: feeding ecology in the central region of Brazil
}

\author{
María Adelaida Hoyos ${ }^{1,3,4}$ \& Selma Maria Almeida-Santos ${ }^{2,3}$ \\ ${ }^{1}$ Universidade da Região de Joinville, Pós-graduação em Saúde e Meio Ambiente, Joinville, SC, Brazil \\ ${ }^{2}$ Instituto Butantan, Laboratório de Ecologia e Evolução, São Paulo, SP, Brazil \\ ${ }^{3}$ Pós-graduação em Anatomia dos Animais domésticos e Silvestres, Faculdade de Medicina Veterinária e \\ Zootecnia, Universidade de São Paulo, USP, Av. Prof. Dr. Orlando Marques de Paiva, 87 CEP 05508270 , \\ Cidade Universitária, São Paulo, SP, Brazil \\ ${ }^{4}$ Corresponding author: María Adelaida Hoyos, e-mail: madelaidaha@gmail.com
}

HOYOS, M.A., ALMEIDA-SANTOS, S.M. The South-American rattlesnake Crotalus durissus: feeding ecology in the central region of Brazil. Biota Neotropica. 16(3): e20140027. http://dx.doi.org/10.1590/16760611-BN-2014-0027

\begin{abstract}
We investigated food patterns in the diet composition of 452 specimens of Crotalus durissus from Central Brazil. Thirty-three items were recorded corresponding to four categories: rodents (75.76\%), marsupials $(6.06 \%)$, unidentified mammals (9.09\%) and reptiles (9.09\%). Adults of both sexes and some juveniles feed mostly on mammals, specifically rodents, it is the most active and abundant prey throughout the year mainly in areas from Cerrado. In addition, we observed that in $C$. durissus there is a trend in the diet of females could be more diverse, maybe this can be associated to sexual differences involving different strategies of the feeding biology of this rattlesnake. Keywords: diet composition, mammal specialization, lizards, Cerrado.
\end{abstract}

HOYOS, M.A., ALMEIDA-SANTOS, S.M. La serpiente cascabel sudamericana Crotalus durissus: ecología alimentar en la región central de Brasil. Biota Neotropica. 16(3): e20140027. http://dx.doi.org/10.1590/16760611-BN-2014-0027

Resumen: Patrones de alimentación fueron investigados en la composición de la dieta de 452 ejemplares de Crotalus durissus de Brasil central. Treinta y tres ítems fueron registrados, correspondientes a cuatro categorías: roedores (75.76\%), marsupiales $(6.6 \%)$, mamíferos no identificados $(9.09 \%)$ y reptiles $(9.09 \%)$. Los adultos de ambos sexos e individuos jóvenes se alimentaron básicamente de mamíferos, en específico de roedores, esta es la presa más activa y abundante durante todo el año, principalmente en las áreas de Cerrado. Además fue observado que en C. durissus existe una tendencia a que la dieta de las hembras sea más diversa, factor que podría estar relacionado a las diferencias sexuales que implican diferentes estrategias de alimentación en la biología de esta serpiente cascabel. Palabras clave: composición de la dieta, especialista en mamíferos, lagartos, Cerrado.

\section{Introduction}

The rattlesnakes of the genus Crotalus evolved in North America and subsequently spread across Central and South America (Echevarrigaray et al. 2000; Quijada-Mascareñas et al. 2007). Currently 41 species of Crotalus are recognized, with greater a diversity in Mexico and the United States (Uetz at al. 2016). This genus is frequently considered as a model for studies related to ecology, due to its widespread distribution covering several habitats, including deserts, flooded areas, forest environments and open habitats (Norman, 1994; Beaupre et al.1998; Place \& Abramson, 2004).

In many species of Crotalus there is ontogenetic variation in diet, with juveniles feeding primarily on ectothermic prey whereas adults prefer endothermic animals as food. Moreover, there is extensive inter- and intraspecific variation in the diet of rattlesnakes. The smaller species, feed primarily on arthropods, amphibians and lizards whereas larger species feed on lizards and small mammals (Klauber 1956, 1972). For instance, adult Crotalus horridus from several regions of the United States (Clark 2002) as well as $C$. viridis in southeast Idaho (Diller \& Wallace 1996) feed mainly on birds and small mammals. Crotalus vegandris from Venezuela (Pífano \& Rodriguez-Acosta 1996), C. pricei, and C. lepidus from some areas in Mexico and the United States (Holycross et al. 2002; Prival et al. 2002), feed on centipedes, lizards, and snakes. However, a divergence in the diet composition was detected in two populations of $C$. lepidus at Big Bend National Park, Texas (Beaupre 1995). In a similar way, the diet of C. viridis oreganus from California is more diverse when compared to $C$. viridis from British Columbia, mainly because of the greater importance of ectothermic prey (Macartney 1989).

The South-American Rattlesnake Crotalus durissus, is restricted to South America (Campbell \& Lamar 2004) and has a discontinuous distribution (Wüster et al. 2005) from Colombia to Argentina (Vanzolini et al. 1980). Some populations exhibit considerable ecological variation, with closeby populations differing greatly from each other (Campbell \& Lamar, 2004). 
In Brazil, Crotalus durissus is widely distributed, except for the states of Acre and Espírito Santo. In addition, there are isolated populations in open areas within savannas of the Amazonian Forest (Campbell \& Lamar 1989). The diet of the species is assumed to be characterized by an extreme specialization in endothermic prey; a feature that exists for only a few species of rattlesnake and which is thought to represent an ancestral trait (Clark 2002). Studies of food composition in populations from southeastern Brazil indicated that rodents and small marsupials were the prey more widely eaten by rattlesnakes (Sant'Anna \& Abe 2007); however, birds (Vanzolini et al. 1980) and lizards (Santos \& Germano 1996), can be considered as occasional food items in the $C$. durissus diet. In this work, we describe the feeding ecology of Crotalus durissus in the central region of Brazil and discus some strategies involved in the feeding of this rattlesnake.

\section{Material and Methods}

The snakes examined represent a total of 452 individuals of Crotalus durissus from the central region of Brazil covering forest formations of the Amazon and Atlantic forests, Caatinga and Cerrado; identified as 213 males, 167 females and 72 neonates and juveniles. We considered specimens to be neonates when their snout-vent length was smaller than $400 \mathrm{~mm}$ (Hoyos, 2012). The specimens are housed in the scientific collections of Instituto Butantan (IBSP), Museu de Zoologia da Universidade de São Paulo (MZUSP), and Universidade de Brasília (CHUNB). Animals kept in captivity prior to being deposited in a scientific collection were excluded from this study.

All food items were removed from the stomach and identified to the lowest possible taxonomic level. Each of the contents was deposited in a glass container with the same identification number as the specimen (voucher number). The intestinal content was determined while taking into account the type of food residue. In addition, available literature records of prey were included in this study, which analyzed the food composition for Crotalus durissus from southeastern Brazil (Santos \& Germano 1996; Sant'Anna \& Abe 2007).

\section{Results}

Thirty-three items were recorded in $30(7 \%)$ stomachs. Approximately $52(12 \%)$ of the intestines contained hair. Four prey categories were identified in the stomachs, the main being rodents $75.76 \%$ (Figure 2), marsupials $6.06 \%$, followed by unidentified mammals $9.09 \%$ and reptiles $9.09 \%$ (Figure 3). The rodents were registered in almost all forest formations studied; marsupials were registered only in Cerrado sites, and lizards in areas of Caatinga and Cerrado (Figure 1) (Appendix 1). In addition, these results show a slight trend towards increased consumption of lizards in females. Evidence for ontogenetic or sexual variation was not detected (Table 1).

Overall, the diet composition of the South-American Rattlesnake Crotalus durissus, considering information of stomach contents identified from specimens in this study in combination with literature records (Santos \& Germano 1996; Sant'Anna \& Abe 2007), show a similar feeding patterns: rodents $66.05 \%$, marsupials $3.98 \%$, unidentified mammals $28.38 \%$ and reptiles $1.59 \%$; in reference to the reptiles, only six specimens - four of which identified in females had reptiles in their stomach.

\section{Discussion}

Considering data to other viperids (Sawaya et al. 2008; Marques et al. 2009; Barbo et al. 2011) the frequency of individuals of Crotalus durissus with prey in the stomach was low.

The elapsed time between capture of the snake and its preservation probably is a reason for the low number of prey in the stomach. This is also supported by Sant'Anna \& Abe 2007, where the stomach content of C. durissus from southeaster Brazil showed a much lower proportion than the gut content.

Approximately 90 percent of rattlesnakes of the genus Crotalus, exhibit ontogenetic shifts in food composition, changing from ectothermic to endothermic preys. These variations could be attributed to changes in morphological, behavioral and physiological characteristics during ontogeny (Mushinsky 1987). Alternatively a small percentage of rattlesnakes feed almost exclusively on endothermic preys, like C. durissus (Salomão et al. 1995; Duarte 2003), C. horridus and C. molossus (Clark 2002). Klauber (1956) gathered these three species and another, C. basiliscus, in the "durissus group", to demonstrate this specialization.

Mammal specialization may be related to several life history strategies (Martins et al. 2002). In some species of pitvipers, it could be associated with the increased venom toxicity in juveniles; this may be a consequence of the need to immobilize larger prey such as a mammal (Andrade \& Abe 1999). Furthermore, the adoption of a juvenile diet based on mammals is more profitable energetically than an ecthothermic diet (Martins et al. 2002). In Crotalus durissus populations, the low frequency of ectothermic prey could explain such eventual facts.

Given this, behavioral and physiological changes necessary to switch from finding and consuming relatively sedentary ectotherms to finding and consuming fast, active endotherms might be costly (Clark 2002). Moreover, the microhabitat to which similar species are adapted to may not be used by local populations of reptiles that could serve as appropriate prey (Reinert 1984).

Several authors, point out the endothermic preys as a determinant element in food composition of C. durissus. For example, Beebe (1946) indicated that a specimen of this rattlesnake from Guyana contained a spiny rat. In populations from Uruguay, Achavál et al. (1978) reported that this rattlesnake commonly feeds on Cavia pamparum. Sant'Anna \& Abe (2007), studying populations of southeastern Brazil, we observed that some species of rodents of the Caviidae and Muridae families followed by marsupials of the group Didelphidae, were the items most frequently consumed in this region.

In the current study, the diet composition of $C$. durissus was similar, characterized by a greater proportion of rodents. This mammals' group is terrestrial, nocturnal and dwell in open areas but they can also be found in forests (Emmons \& Feer 1990; Nowak 1991). Similarly, in Cerrado endothermic prey types are rich and abundant, about 194 species of mammals are recognized, in which 51 are rodents and 17 marsupials (Marinho-Filho et al. 2002). This number has increased with the description of new species and the expansion of occurrence area of others (Bonvicino et al. 2003; Bonvicino et al. 2010).

In C. durissus, juveniles and adults feed predominantly on rodents (Sant'Anna \& Abe 2007), a pattern attributed to the overall availability of this type of prey (Salomão et al. 1995). Field work confirmed an absence of ontogenetic variation in the diet which indicated that the juveniles of this rattlesnake could survive in dry locations with a supply 


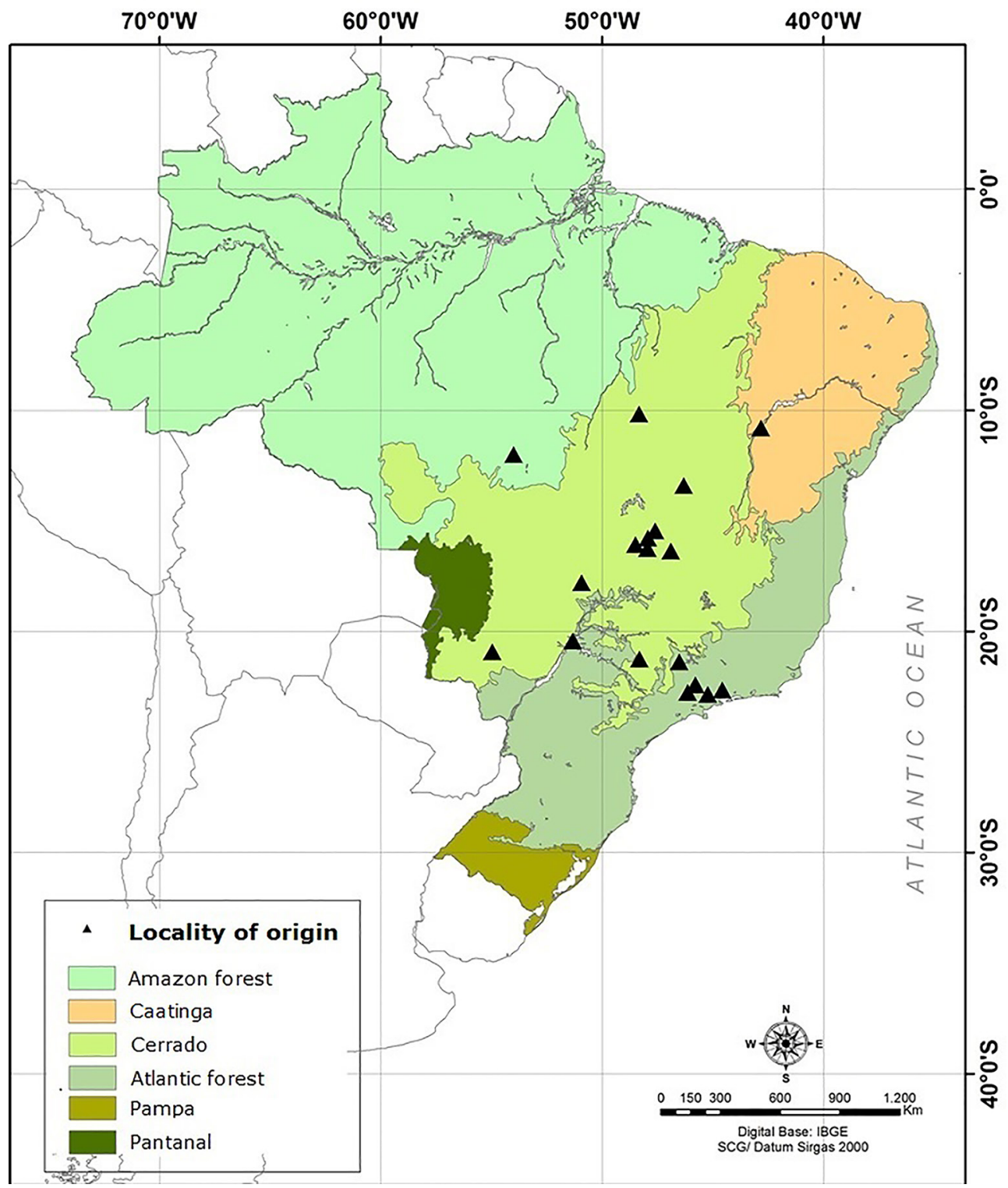

Figure 1. Geographical distribution of Crotalus durissus with stomach contents from Central Region of Brazil covering forest formations of Amazon and Atlantic forest, Caatinga and Cerrado.

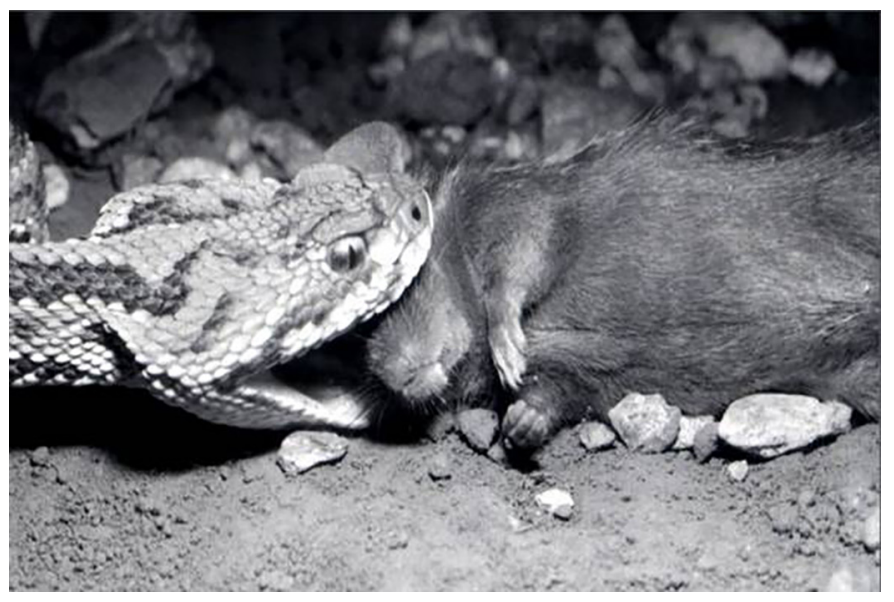

Figure 2. Food category (rodent) of Crotalus durissus from Distrito Federal.

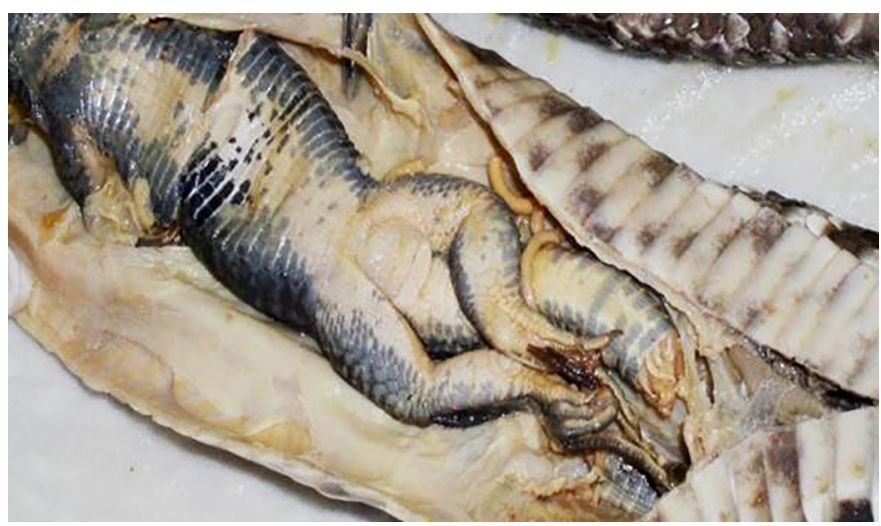

Figure 3. Food item, Ameiva ameiva, recorded in the stomach of a female Crotalus durissus. Specimen deposited in the Coleção Herpetológica da Universidade de Brasília (CHUNB 49673). 
Hoyos, M.A. et al.

Table 1. Food composition in individual males, females, newborns and juveniles of Crotalus durissus from Central Region of Brazil ( $n=30$ snakes).

\begin{tabular}{|c|c|c|c|c|c|}
\hline Categories of preys & Males & Females & Newborns/Juveniles & $\mathbf{F}$ & F\% \\
\hline \multicolumn{6}{|l|}{ Mammalia } \\
\hline Not identified & & 3 & & 3 & 9.09 \\
\hline \multicolumn{6}{|l|}{ Marsupialia } \\
\hline Didelphidae & 1 & & 1 & 2 & 6.06 \\
\hline Ameiva ameiva & & 2 & 1 & 3 & 9.09 \\
\hline Total & 10 & 15 & 8 & 33 & 100 \\
\hline
\end{tabular}

of rodents (Tozetti \& Martins 2008). The consumption of rodents in all age classes and both sexes is favored because this prey is the most abundant throughout the year. Yet teid lizards (Ameiva) (Santos \& Germano 1996) can be a sporadic food item in rattlesnakes. The teid Ameiva ameiva, is relatively abundant in Cerrado sites (Araujo \& Almeida-Santos 2012) and even near human settlements (Colli et al. 2002), usually occupying similar habitats to Crotalus durissus. This could be one of the reasons that this species is more frequently consumed rather than other ectothermic prey.

Additionally, some factors such as adaptations related to competition, niche utilization, foraging strategies, costs of time and energy and prey availability (Schoener 1969; Shine 1986; Shine et al. 2002), could reflect important characteristics in the understanding of feeding ecology of C. durissus from the central region of Brazil.

\section{Appendix 1}

Collection sites with voucher numbers of studied specimens of Crotalus durissus and stomach contents from Central Region of Brazil. CHUNB, Coleção Herpetológica da Universidade de Brasília; IBSP, Instituto Butantan; MZUSP, Museu de Zoologia da Universidade de São Paulo.

BAHIA: Ibiraba (MZUSP 10076) - one lizard. DISTRITO FEDERAL: Brasília (CHUNB 5439, 22100) - three rodents. GOIÁS: Alexânia (CHUNB 20432) - one unidentified mammal; Luziânia (CHUNB 20468) - one rodent; Planaltina (CHUNB 20444, 20446, 20467) - three rodents; Rio verde (CHUNB 49673, IBSP 11997) one lizard and one marsupial; São Domingos (CHUNB 15499) - one unidentified mammal. MINAS GERAIS: Camanducaia (CHUNB 67995) - one rodent; Conceição dos Ouros (IBSP 68493) - one rodent; Muzambinho (CHUNB 24288) - one rodent; Unaí (CHUNB 20460, 20475-76, 24379) - one lizard, one unidentified mammal and two rodents. MATO GROSSO: Parque Xingú (CHUNB 28739) - one rodent. MATO GROSSO DO SUL: Ilha Solteira (IBSP 38087) one rodent; Sidrolândia (IBSP 23922) - one rodent. SÃO PAULO: Aparecida do Norte (IBSP 73254) - one rodent; Jaboticabal (IBSP 23682) - one rodent; São José do Barreiro (IBSP 71480 - 71482) - three rodents. TOCANTINS: Palmas (CHUNB 14690) - one rodent. In relation to three specimens from Cerrado, two of them contained two rodents respectively and the other one marsupial; for these snakes the collection sites were undetermined.

\section{Acknowledgements}

We would like to thank the curators, collection managers and technical assistants. We are grateful to Guarino R. Colli for the orientation during the research in the masters' degree, Otavio A. V. Marques for their contribution through comments and suggestions for this study and Valdir J. Germano for helping with the prey identification. We also thank Antonio Sebben, Yara de Mello, for the help in obtaining rattlesnake photographs along with map elaboration and Paul Graeme Reynolds for the English review and the final revision of the manuscript.

\section{References}

ACHAVAL, F., MELGAREJO, A. \& MENEGHEL, M. 1978. Ofidios del área de influencia de Salto Grande (aspectos biológicos y referencias sobre ofidismo). V Reunión sobre aspectos del Desarrollo Ambiental. Salto (R. O. U.) - Concordia (R. A.). Comisión Técnica Mixta de Salto Grande. Gerencia Salud, Ecología y Desarrollo Regional. República Argentina, República Oriental del Uruguay.

ANDRADE, D. V. \& ABE, A.S. 1999. Relationships of venom ontogeny and diet in Bothrops. Herpetologica 55:200-204.

ARAUJO, C.O. 2012. Composição, riqueza e abundância de anfíbios e répteis no Alto e Médio Paranapanema, Estado de São Paulo. Tese de doutorado, Universidade de São Paulo, São Paulo.

BEAUPRE, S.J. 1995. Comparative ecology of the mottled rock rattlesnake, Crotalus lepidus, in Big Ben National Park. Herpetologica 51(1):45-56.

BEAUPRE, S.J., DUVALL, D. \& O'LEILE, J. 1998. Ontogenetic variation in growth and sexual size dimorphism in a Central Arizona population of the western diamondback rattlesnake (Crotalus atrox). Copeia 1:40-47.

BEEBE, C.W. 1946. Field notes on the snakes of Kartabo, British Guaiana and Caripito, Venezuela. Zoologica -NY. 31(1-4):11-52.

BARBO, F.E., MARQUES O.A.V. \& SAWAYA R.J. 2011. Diversity, natural history, and distribution of snakes in the municipality of São Paulo. SAJH. 6(3):135-160

BONVICINO, C.R., LIMA, J.F.S \& ALMEIDA, F.C. 2003. A new species of Calomys Waterhouse (Rodentia: Sigmodontinae) from the Cerrado of Brazil cental. Revista Brasileira de Zoologia 20(2):301-307.

BONVICINO, C.R., OLIVEIRA, J.A. \& GENTILE, R. 2010. A new species of Calomys (Rodentia: Sigmodontinae) from eastern Brazil. Zootaxa 2336:19-25.

CAMPBELL, J.A. \& LAMAR, W.W. 1989. The venomous reptiles of Latin America. Cornell University Press, Ithaca.

CAMPBELL, J.A. \& LAMAR, W.W. 2004. The venomous reptiles of the western hemisphere. Cornell University Press, Ithaca.

COLLI, G.R., BASTOS, R.P. \& ARAUJO, A.F.B. 2002. The character and dynamics of the Cerrado herpetofauna. In: The Cerrados of Brazil: ecology and natural history of a Neotropical savanna (P.S. Oliveira \& R.J. Marquins, eds). Columbia University Press, New York, p. 223-241. 
CLARK, R.W. 2002. Diet of the timber rattlesnake Crotalus horridus. J. Herpetol 36(3):494-499.

DILLER, L.V. \& WALLACE, R.L. 1996. Comparative ecology of two snake species (Crotalus viridis and Pituophis melanoleucus) in southwestern Idaho. Herpetologica 52(3):343-360. http://dx.doi.org/10.2307/3892654

DUARTE, M.R. 2003. Prickly food: snakes preying upon porcupines. Phyllomedusa 2(2):109-112.

ECHEVERRIGARAY, S., GRAZZIOTIN, G., GRAZZIOTIN, F. \& AGOSTINI, G. 2000. Random Amplified Polymorphisms between two South American subspecies of rattlesnakes (Crotalus durissus collilineatus e Crotalus durissus terrificus). Braz. Arch. Biol. Techn. 313-317.

EMMONS, L.H. \& FEER, F. 1990. Neotropical rainforest mammals. University of Chicago Press, Chicago.

HOLYCROSS, A.T., PAINTER, C.W., PRIVAL, D.V., SHAWNN, D.E., SCHROFF, M.J., EDWARDS, T. \& SCHWALBE, C.R. 2002. Diet of Crotalus lepidus klauberi (banded rock rattlesnake). J. Herpetol. 36 (4): 589-597. http://dx.doi.org/10.1670/0022-1511(2002)036[0589:DOCLK B]2.0.CO;2

HOYOS, M.A. 2012. A cascavel neotropical Crotalus durissus: uma abordagem morfológica e da história natural em populações do Brasil. Tese de doutorado, Universidade de São Paulo, São Paulo.

KLAUBER, L.M. 1956. Rattlesnakes, their habits, life histories and influence in mankind. 2 vol. University of California Press, Berkeley.

KLAUBER, L.M. 1972. Rattlesnakes, their habits, life histories and influence in mankind. 2 d ed., 2 vol. University of California Press, Berkeley.

MACARTHNEY, J.M. 1989. Diet of the northern pacific rattlesnake, Crotalus viridis oreganus, in British Columbia. Herpetologica 45(3):299-304. http:// dx.doi.org/10.2307/3892885

MARINHO-FILHO, J., REIS, M.L., OLIVEIRA, O.S., VIEIRA, E.M. \& PAES, M.N. 2002. The Cerrado mammals: Diversity, ecology and natural history. In The Cerrados of Brazil: ecology and natural history of a neotropical savanna (P.S. Oliveira \& R.J. Marquins, eds). Columbia University Press, New York, p. 266-284.

MARQUES, O.A.V., PEREIRA, D.N., BARBO, F.E., GERMANO, V.J. \& SAWAYA, R.J. 2009. Os Répteis do Município de São Paulo: diversidade e ecologia da fauna pretérita e atual. Biota Neotrop. 9(2):1-12.

MARTINS, M., MARQUES, O.A.V. \& SAZIMA, I. 2002. Ecological and phylogenetic correlates of feeding habits in Neotropical pitvipers of the genus Bothrops. In Biology of the vipers (G.W. Schuett, M. Höggren, M.E. Douglas \& H.W. Greene, eds). Eagle Mountain Publishing, Utah, p. 1-22.

MUSHINSKY, H.R. 1987. Foraging ecology. In Snakes: ecology and evolutionary Biology (R.A. Seigel, J.T. Collins \& S.S. Novak, eds). Mc-Graw Hill Publishing Company, New York, p. 302-334.

NORMAN, D.R. 1994. Anfibios y reptiles del Chaco Paraguayo. Edición Privada, San José, Costa Rica.

NOWAK, R.M. 1991. Walker's mammals of the world. 5th ed. The Johns Hopkins University Press, Baltimore.

PIFANO, F. \& RODRIGUEZ-ACOSTA, A. 1996. Ecological niche and redescription of Crotalus vegrandis (Serpentes: Crotalidae) in Venezuela. Brenesia 45-46:169-175.
PLACE, A.J. \&. ABRAMSON, C.I. 2004. A quantitative analysis of the ancestral area of rattlesnakes. J. Herpetol. 38(1):151-156. http://dx.doi org/10.1670/103-03N

PRIVAL, D.B., GOODE, M.J., SWANN, D.E., SCHWALBE, C.R. \& SCHROFF, M.J. 2002. Natural history of a northern population of twin-spotted rattlesnakes, Crotalus pricei. J. Herpetol. 36(4):598-607. http://dx.doi. org/10.1670/0022-1511(2002)036[0598:NHOANP]2.0.CO;2

QUIJADA-MASCAREÑAS, J.A., FERGUSON, J.E., POOK, C.E., SALOMÃO, M.G., THORPE, R.S. \& WÜSTER, W. 2007. Phylogeographic patterns of trans-Amazonian vicariants and Amazonian biogeography: the Neotropical rattlesnake (Crotalus durissus complex) as an example. J. Biogeogr 34:1296-1312. http://dx.doi.org/10.1111/j.1365-2699.2007.01707.x

REINERT, H.K. 1984. Habitat variation within sympatric snake populations. Ecology 65:1673-1682. http://dx.doi.org/10.2307/1939146

SALOMÃO, M.G., ALMEIDA-SANTOS, S.M. \& PUORTO, G. 1995. Activity pattern of Crotalus durissus (Viperidae, Crotalinae): Feeding, reproduction and snakebite. Stud. Neotrop. Fauna E. 30(2):101-106.

SANTOS, S.M. \& GERMANO, V.J. 1996. Crotalus durissus (Neotropical rattlesnake) Prey. Herpetol. Rev. 27(3):143.

SANT'ANNA, S. \& ABE A.S. 2007. Diet of the rattlesnake Crotalus durissus in southeastern Brazil (Serpentes, Viperidae). Stud. Neotrop. Fauna E. 42(3):169-174. http://dx.doi.org/10.1080/01650520601148313

SAWAYA, R.J., MARQUES, O.A.V. \& MARTINS, M. 2008. Compisition and natural history of a Cerrado snake assemblage at Itirapina, São Paulo state, southeastern Brazil. Biota Neotrop. 8:127-149.

SCHOENER, T.W. 1969. Models of optimum size for solitary predators. Amer. Natur. 103:227-313.

SHINE, R. 1986. Sexual differences in morphology and niche utilization in an aquatic snake, Acrochordus arafurae. Oecologia 69:260-267. http://dx.doi org/10.1007/BF00377632

SHINE, R., REED, R.N., SHETTY, S. \& COGGER, H.G. 2002. Relationships between sexual dimorphism and niche partitioning within a clade of seasnakes (Laticaudinae). Oecologia 133:45-53. http://dx.doi.org/10.1007/ s00442-002-1012-7

TOZETTI, A. M., \& MARTINS, M. 2008. Habitat use by the South-American rattlesnake (Crotalus durissus) in southeastern Brazil. Journal of Natural History 42:1435-1444. http://dx.doi.org/10.1080/00222930802007823

UETZ, P. The Reptile Database. Zoological Museum Hamburg, Germany. http:/ www.reptile-database.org (last accessed in 15/03/2016).

VANZOLINI, P.E., RAMOS-COSTA, A. \& VITT, L.J. 1980. Répteis das Caatingas. Academia Brasileira de Ciências, Rio de Janeiro.

WÜSTER, W., FERGUSON, J.E., QUIJADA-MASCAREÑAS, J.A., POOK, C.E. \& SALOMÃO, M.D. 2005. Tracing an invasion: landbridges, refugia, and the phylogeography of the Neotropical rattlesnake (Serpentes: Viperidae: Crotalus durissus). Mol. Ecol. 14(4):1095-1108. http://dx.doi. org/10.1111/j.1365-294X.2005.02471.X 